\title{
A tribute to Smolíková (1971): Principles of soil development in the Quaternary
}

\author{
Lenka Lisá $^{1}$ and Aleš Bajer ${ }^{2}$ \\ ${ }^{1}$ Institute of Geology, Czech Academy of Sciences, Rozvojová 269, Prague 6, 165 00, Czech Republic \\ ${ }^{2}$ Department of Geology and Soil Science, Faculty of Forestry and Wood Technology, \\ Mendel University in Brno, Brno, 613 00, Czech Republic
}

Correspondence: $\quad$ Lenka Lisá (lisa@gli.cas.cz)

Relevant dates: $\quad$ Received: 1 June 2021 - Revised: 8 November 2021 - Accepted: 12 November 2021 Published: 17 December 2021

How to cite: $\quad$ Lisá, L. and Bajer, A.: A tribute to Smolíková (1971): Principles of soil development in the Quaternary, E\&G Quaternary Sci. J., 70, 247-250, https://doi.org/10.5194/egqsj-70-247-2021, 2021.

Special issue statement. This article is part of a special issue published on the occasion of the 70th anniversary of $E \& G$ Quaternary Science Journal (EGQSJ). The special issue celebrates the journal's notable contribution to Quaternary research by revisiting selected milestone articles published in the long history of EGQSJ. The German Quaternary Association (DEUQUA) presents translations of the originals and critical appraisals of their impact in tandem anniversary issues of DEUQUASP and EGQSJ, respectively.

Original article: https://doi.org/10.3285/eg.22.1.12

Translation: https://doi.org/10.5194/deuquasp-3111-2021

\section{Soils in the context of Quaternary studies of} Czechoslovakia at the end of the last century

To better understand Libuse Smolíková's background and study, one needs to understand the beginnings of cooperation between soil science, Quaternary geologists and archeologists in the former Czechoslovakia. The concept of soil study in the former Czechoslovakia followed the "Russian school". It focused mainly on the genesis of soils, in contrast to the American one, which was directed more economically, i.e., to assess soil fertility. Thanks to this, it was possible at that time to better connect pedological sciences with the study of Quaternary sediments related to climatic changes. One important work on combining soil research and Quaternary studies was from Musil et al. (1955); in this study osteologist, archeologists and soil scientists worked together, mapping the occurrence of paleosols in loess formations in southern and central Moravia and discussing their significance for Quaternary climate cycle dating (Musil et al., 1955). The soil scientist in this study, Pelíšek, used classical pedological methods for the time; i.e., in the field he distinguished macroscopic properties of soil horizons, and in the laboratory he then determined the content of organic matter, carbonates, $\mathrm{pH}$ and grain size composition. Thick loess formations with buried paleosol served as one of the beststudied environmental archives, and its stratigraphical record was assigned to the then valid stratigraphy of the last Quaternary climate cycle. Very detailed study of the sedimentary archives helped to divide more precisely the stratigraphy of the Vistula ("Würm" - see Alpine chronostratigraphy) glacial in the early 1950s. Its division was generally accepted by two fluctuations, which were referred to as "Würm $1 / 2$ " and "Würm 2/3" (respectively LGl 1/2 and LGl 2/3) and which included the soils "Göttweig" (W 1/2) and "Paudorf" (W 2/3) or "Oberfellabrunn" (according to the outcrop in the brickyard in Lower Austria) and "Paudorf" (Brandtner, 1956) or "Stillfried A" and "Stillfried B" (according to the outcrop in Stillfried). Such a division of the last glacial was also ap- 
plied in Czech literature under the term "Soergel-Zeuner system" (Valoch, 2012). Much later, Valoch (2012) published an important study, in which he tried to compare the terminology of the stratigraphic classification of soils of the last glacial cycle used at the time with that corresponding to current knowledge. The reason was that the climatic stratigraphy of the last Quaternary cycle is crucial for the classification of finds of the Middle and Upper Paleolithic and that the important archeological works from the 1960s were based on the stratigraphical terminology valid at that time.

\section{The main messages of Smolíková's work}

Smolíková was one of the first pedologists who pointed out that paleosol horizons in Quaternary paleosol-sediment successions are often described by Quaternary geologists who are not trained in pedology and that it may increase the problems with the interpretations. As a result, many existing descriptions of paleosols in the literature were hardly pedologically interpreted in terms of the kind of pedogenic processes and the environmental conditions that they are indicative of. She pointed out that the description and interpretation of paleosols must be linked to a profound taxonomy of soils, including all kinds of soil formation in all possible stages of development. Smolíková (1971) further highlighted the importance of the position of the soil profile in the landscape and that the influence of relief has to be considered. If possible, soil horizons should be observed along some distance in order to recognize reworking, disturbance and accumulation of soil sediments.

Her seminal paper discussed here is an outstanding example of how the views of geologists, environmentalists and archeologists on pedocomplexes can be united. The concept of Quaternary climatic division was followed by Smolíková in her micromorphological description of pedocomplexes (Němeček et al., 1990), and its link to the soil genesis and environmental conditions under which pedocomplexes developed represent the main message of her work. The problems of this "early" paleopedological work was the non-stable soil terminology. Smolíková often described the micromorphological properties and linked them to the types of soils which are, however, recently not used any more. Later, when the pedological system changed, Smolíková did not adapt her terminology to it. Therefore, it is complicated to use the terminology and interpretation from the time when she investigated the old localities (Adameková et al., 2021). Another problem with the application of her terminology applied to the pedocomplexes is due to the increasing knowledge of climatic changes. Since the publication of Smolíková's work, i.e., over the last 50 years, the understanding of the situation of the climatic development of the last glacial cycle in Central Europe, as well as the understanding of the situation of the Paleolithic, has changed significantly. The system of pedocomplexes, which document the so-called warm phases (interglacials or interstadials), is only suitable for a more general division of the entire Pleistocene. On a detailed scale, however, they are often unsatisfactory.

\section{Pedocomplexes and paleopedological provinces} in the light of Smolíková's work

An example of the unsatisfactory basic division is the last glacial, in which Smolíková separated two pedocomplexes called PKI and PKII. However, later research revealed that there had developed another paleosol between these two pedocomplexes, the preservation of which is simultaneously affected by erosion processes. This pedocomplex is the socalled Bohunice soil after its eponymous locality, Bohunice in Brno. From the point of view of Paleolithic research, this pedocomplex is crucial because industry from the turn of the Middle and Upper Paleolithic (early Upper Paleolithic: Bohunician, Szeletian, Aurignacian) is tied to it. Later, Smolíková, as a co-author in the first comprehensive monograph on pedology and paleopedology published in Czechoslovakia (Němeček et al., 1990), significantly expanded the paleopedological and paleogeographic concepts published in her article commented upon herein concerning the use of pedological data in the Quaternary. There, she described in detail the importance of paleopedology for the understanding of paleoclimate and paleogeography during the Quaternary in Central Europe. It clearly defined the patterns of soil development in the Quaternary cycle and emphasized the importance of soils as part of Quaternary geology. Probably the most important contributions to the study of Quaternary paleosols are specific micromorphological descriptions of these soils and a description of the genesis of these soils on individual soil-forming substrates preserved in a whole range of Quaternary sediments, especially in loess.

To connect pedology with Quaternary research, Smolíková used a basic methodological tool, namely the microstructure of soils, i.e., the so-called soil micromorphology. In addition to the microstructure itself, the type and degree of preservation of organic and organomineral soil components can be described, as well as the pedofeatures related to soil development; further, post-sedimentary processes can be detected. This can be quite complex and might reflect the changing climatic conditions of the site.

The study of soil microstructure was introduced into the literature in the 1930s by Kubiëna (exact year unknown). Smolíková was a student of Kubiëna and took over his terminology, which she began to apply to the study of paleosols in the Central European context in the 1960s. In the 1960s, Brewer (1964) proposed a more systematic, morphological approach to the description of soil samples, followed by a number of other authors. The efforts of the 3rd International Meeting on Soil Micromorphology in Wroclaw (Poland) in 1969 resulted in a long-term accepted terminology and a standard way to describe thin sections (Bullock et al., 1985). 
This terminology is widely used up today, but most of the researchers combine that terminology with the more systematic terminology of Stoops (2003).

At the time when Smolíková published her annotated article, interest in the importance of paleosols was not only in the context of archeology (Lisá et al, 2015), but it intensified especially in the 1970s when Kukla suggested to the president of the United States the importance of studying paleosols in the context of future climate change (i.e., global cooling versus global warming). On this account, Kukla created the above-mentioned concept of pedocomplexes, which Smolíková elaborated in terms of soil micromorphology (Němeček et al., 1990). The principles on the basis of which pedocomplexes were determined are described in great detail in her 1971 article. Smolíková's (1971) article, and the way in which it used soil micromorphology, was therefore completely original for its time. In our opinion, it has become a building stone for further studies of a similar type. Since then, a number of studies have been published in which soil micromorphology has played a crucial role in recognizing soil processes that reflect the relatively complex conditions of a changing climate.

Further, Smolíková (1971) showed one very important aspect when interpreting the differences in soil development. In her work, she strongly refers to zonal concepts that have also become outdated. Recent and subrecent soil cover that developed on loess substrate over the Holocene in Central and Western Europe differs according to the continental gradient and as a result of orographic influences (e.g., rain shadow effect). Such effects controlled the spatial differences in pedogenesis in loess also under past climatic conditions. Smolíková (1971) also pointed out the importance of comparing pedological characteristics of paleosols with their modern analogs, which allows for the reconstruction of the climatic conditions that prevailed during their formation. In this respect, she highlights the use of micromorphology, together with pollen, kernels of fruits, phytoliths, rhizoliths, and mollusk shells, for a detailed characterization of the pedogenic features that can be identified in a paleosol. Her recommendations were crucial for understanding the importance of the identification of the environmental conditions when interpreting buried paleosols.

\section{Current state of knowledge, perspectives and trends}

Soil micromorphology has undergone relatively fundamental changes in the terminology and possibilities of instrumentation since Smolíková (1971) used it - or, better, introduced it - in her article. While its importance for the study of recent soils has declined, it has become an integral part of paleopedological research and at the same time an innovative tool for anthropogenic sediment research. Unfortunately, the conditions in Czechoslovakia did not allow Smolíková (1971) to innovate the ways of studying soil excavations in the direction they went in Western Europe. Therefore, its descriptions and terminology published after 2000 use more or less the original terminology and are thus often deprived of the context that can be obtained by using new terminology and methodological approaches. Examples are the size of the samples used for the study, the use of an electron microscope or a UV microscope, or the detection of pedofeatures, which have not been given the deserved recognition in the past. For example, Fitzpatrick's ingenious work can be a parallel. His system and comparative collection, very innovative for its time, are currently basically unusable. As was the case with Fitzpatrick, the importance of soil micromorphology in Quaternary studies gradually disappears after Smolíková stopped her active work. Smolíková's micromorphological terminology (1971) used to distinguish pedocomplexes is not only due in her time to the style of marking pedofeatures but is also interpretatively linked to the pedological system of that time. Today, there is basically nothing like a conversion table between soils described and interpreted on the basis of soil micromorphology by Smolíková and the current pedological system. Therefore, any comparison of recent terminology with older works is very difficult and nearly impossible in some cases (Adameková et al., 2021). Firstly, this is because soil traits are mostly tied to regional conditions (Hošek et al., 2017; Lisá et al., 2015), so within soil catena, different looking pedocomplexes may form during one climatic cycle (e.g., Adameková et al., 2021). The second reason is that buried soil horizons are often complex and strongly affected by soil erosion. Another and probably the most important factor that fundamentally complicates the inclusion of soil pedocomplexes in the current pedological system is that if the soils were not covered with loess or colluvial sediments, new soils began to form under the new climatic conditions but from the substrate of older soils. In such a case, soil micromorphology is an invaluable tool for detecting not so much the inclusion of soil in the system but rather the processes that lead to pedogenesis. It is evident that soil micromorphology is a key tool for detecting climate change. Today, much more sophisticated methods are preferred for climate studies, such as isotope studies and comparisons of regional records with, for example, marine or glacier climate archives. Studies that have over-generalized and underestimated the importance of soils have unnecessarily led, for example, to the creation of pseudo-terms such as "Podhradem interstadial". Such dogmas are then very difficult to overcome, but new methodological approaches combined with soil micromorphology can help to solve such problems (Lisá et al., 2018). Today, soil micromorphology is not the preferred method to study paleosols or soils. It is often replaced by chemical methods, and although soil geochemistry is highly suitable, it can never replace a direct view of the internal structure of the soil. Soil micromorphology should therefore remain a necessary reference of processes and an integral part of environmental Quaternary research. 
Financial support. The article processing charge was funded by the Quaternary scientific community, as represented by the host institution of EGQSJ, the German Quaternary Association (DEUQUA).

Review statement. This paper was edited by Christine Thiel and reviewed by one anonymous referee.

\section{References}

Adameková, K., Lisá, L., Neruda, P., Petř́k, J., Doláková, N., Novák, J., and Volánek, J.: Pedosedimentary record of MIS 5 as an interplay of climatic trends and local conditions: Multi-proxy evidence from the Palaeolithic site of Moravský Krumlov IV (Moravia, Czech Republic), Catena, 200, 105174, https://doi.org/10.1016/j.catena.2021.105174, 2021.

Brandtner, F.: Lößstratigraphie und paläolithische Kulturabfolge in Niederösterreich und den angrenzenden Gebieten (Zugleich ein Beitrag zur Frage der Würmgliederung), E\&G Quaternary Sci. J., 7, 127-175, https://doi.org/10.3285/eg.07.1.13, 1956.

Brewer, R.: Fabric and mineral analysis of soils, John Wiley \& Sons, New York, USA, 1964.

Bullock, P., Fedoroff, N., Jorgerius, A., Stoops, G., Tursina, T., and Babel, U.: Handbook for soil thin section description, Waine Research Publications, Wolverhampton, UK, 1985.
Hošek, J., Lisá, L., Hambach, U., Petr, L., Vejrostová, L., Bajer, A., Matys Grygar, T., Moska, P., Gottvald, Z., and Horsák, M.: Middle Pleniglacial pedogenesis on the northwestern edge of the Carpathian basin: A multidisciplinary investigation of the Bíňa pedo-sedimentary section, SW Slovakia, Palaeogeogr. Palaeocl., 487, 321-339, 2017.

Lisá, L., Hošek, J., Bajer, A., Matys Grygar, T., and Vandenberghe, D.: Geoarchaeology of Upper Palaeolithic loess sites located within a transect through Moravian valleys, Czech Republic, Quatern. Int., 351, 25-37, 2015.

Lisá, L., Neruda, P., Nerudová, Z., and Nejman, L.: Podhradem Interstadial. A critical review of the middle and late MIS 3 (Denekamp, Hengelo) in Moravia, Czech Republic, Quaternary Sci. Rev., 182, 191-201, 2018.

Musil, R., Valoch, K., and Nečesaný, V.: Pleistocénní sedimenty okolí Brna. - Sbor. geol. Věd, Anthropozoikum, 4, 107-168, 1955.

Němeček, J., Kutílek, M., and Smolíková, L.: Pedologie a Paleopedologie, Academia, Prague, Czech Republic, 546 pp., 1990.

Smolíkovaá, L.: Gesetzmäßigkeiten der Bodenentwicklung im Quartär, E\&G Quaternary Sci. J., 22, 156-177, https://doi.org/10.3285/eg.22.1.12, 1971.

Stoops, G.: Guidelines for Analysis and Description of Soil and Regolith Thin Sections, Soil Science Society of America, Madison, WI, USA, 2003.

Valoch, K.: K historii členění würmského/viselského glaciálu v českých zemích, Archeologické rozhledy, LXIV, 129-135, 2012. 